\title{
PENGEMBANGAN MEDIA POP-UP BOOK UNTUK MATA PELAJARAN IPA BAB SIKLUS AIR DAN PERISTIWA ALAM SEBAGAI PENGUATAN KOGNITIF SISWA
}

\author{
Tri Wahyu Ningtiyas, Punaji Setyosari, Henry Praherdiono \\ Teknologi Pendidkan, Fakultas Ilmu Pendidikan, Universitas Negeri Malang \\ Jalan Semarang No. 5 Malang Jawa Timur Indonesia \\ Email:twnyass@gmail.com
}

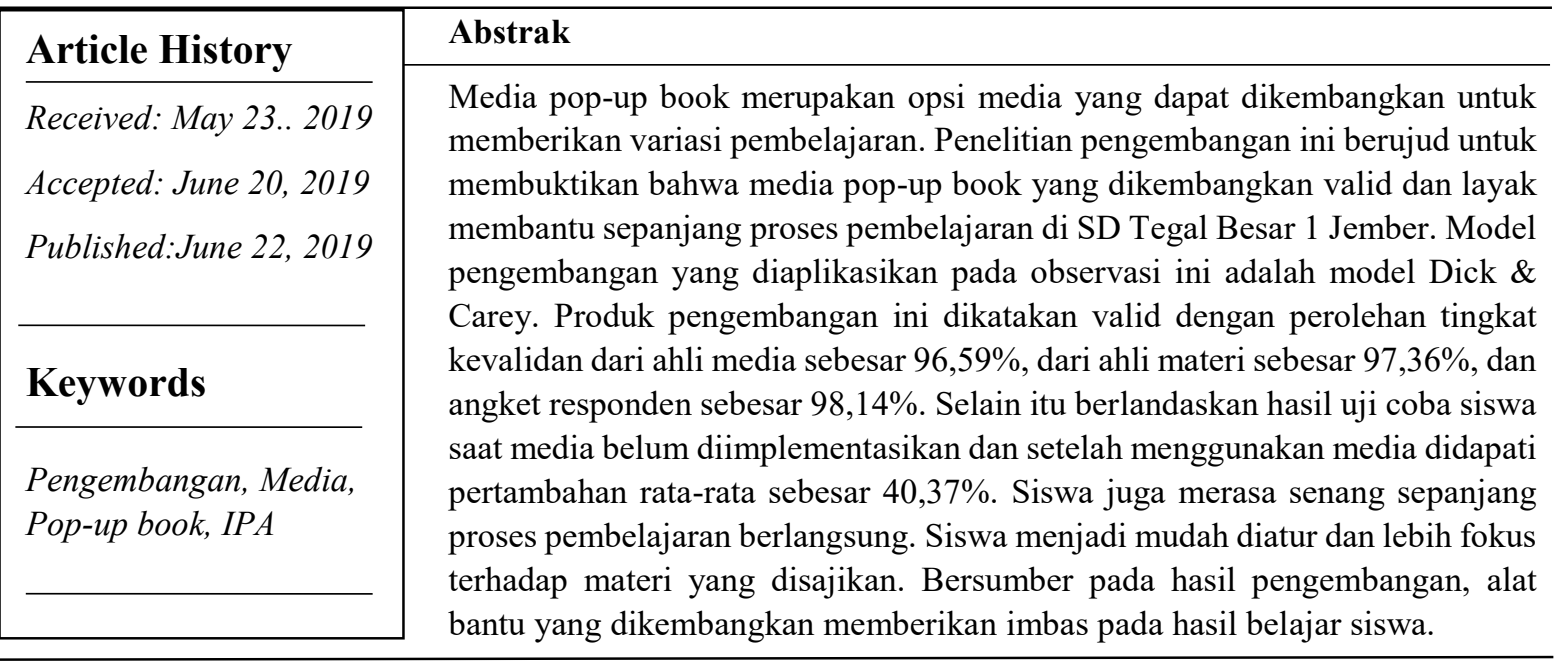

\section{PENDAHULUAN}

SDN Tegal Besar 1 Jember merupakan lembaga pendidikan di Kabupaten Jember yang menggunakan modul untuk mendukung proses pembelajaran. Salah satu pelajaran yang mengenakan modul sebagai media ajar adalah IPA. Pada sub bab daur air dan peristiwa alam guru menggambar materi dipapan tulis sebagai pendukung modul. Mekanisme pembelajaran seperti ini, banyak peluang yang terjadi seperti siswa tidak memperhatikan saat guru menerangkan, siswa tidak belajar dengan tenang dan pasif sehingga minat baca siswa berkurang. Minat membaca seharusnya mulai ditumbuhkan saat anak-anak, sehingga seiring bertambahnya usia, hasrat membaca anak tersebut juga mengalami pertambahan. Oleh karenanya, dibutuhkan bahan bacaan yang mana si anak bisa bermain sambil belajar. Selain itu, bahan bacaan tersebut juga harus menarik hati si anak (Siregar:2016). Menurut Hayat \& Yusuf dalam (Mustofa:2018) Capaian hasil belajar IPA siswa di Indonesia saat ini yang tergolong rendah dipengaruhi oleh banyak faktor, yaitu karakteristik siswa dan keluarga, kecakapan membaca, dorongan belajar, ketertarikan dan konsep diri, strategi belajar, tingkat kehadiran dan rasa memiliki. Paham tersebut sebanding dengan hasil peninjauan yaitu, dorongan siswa untuk menggali ilmu mudah melemah saat pembelajaran, sehingga dibutuhkan perangkat penunjang belajar yang mampu mengarahkan fokus belajar. Sementara itu guru diwajibkan merampungkan pembelajaran tepat waktu. Di sekolah tersebut media yang dianggap ampuh adalah buku modul, walaupun tampak beberapa siswa 
kesukaran menggunakan buku. Pengajaran akan kian memaut perhatian dan dapat memupuk dorongan belajar para siswa jika media yang digunakan merupakan media yang menarik dan menyenangkan serta sinkron dengan siswa, tidak semata-mata hanya menggunakan kontak lisan melalui pengucapan katakata oleh guru, sehingga siswa tidak menjadi jemu selanjutnya pengajar usah memakan banyak tenaga (Mubarok:2014). Bersumber pada persoalan tersebut direalisasikan media pembelajaran berupa pop up yang diharapkan mampu mendongkrak minat dan hasil belajar siswa. Pop-up ialah media yang menggunakan rekayasa kertas (paper engineering). Pertimbangan pengembang mengaplikasikan pop up lantaran berwujud gambar 3 dimensi, sedangkan selama pembelajaran guru merepresentasikan materi dengan mengilustrasikannya di papan tulis. Menurut pengembang pop up book sanggup menyangga guru untuk menguraikan materi dengan gambar yang lebih detail. Pop up book jua ialah sarana pembelajaran yang tepat untuk siswa lantaran sanggup membagikan pengalaman belajar yang menggembirakan.

Penelitian ini merujuk pada penelitian terdahulu yang dilaksanakan oleh Handaruni Dewanti yang bertajuk Pengembangan Media Pop-Up Book untuk pembelajaran Lingkungan Tempat Tinggalku Kelas IV SDN 1 Pakunden Kabupaten Ponorogo. Hasil penelitian menunjukkan bahwa hasil validasi ahli media diperoleh persentase sebesar 97,79\% . Hasil pengecekan ahli materi diperoleh persentase sebesar $94,93 \%$. Hasil dari ahli pengguna diperoleh persentase sejumlah $95,17 \%$ serta hasil dari uji coba yang dilakukan pada 16 siswa diperoleh persentase sebesar 95\%. menurut hasil pengecekan bahan ajar pop up digolongkan "valid". Sementara perolehan dari pre test dan post test didapati adanya selisih ratarata nilai sebelum dan setelah penggunaan media yakni 55,625 dan 82,5 dengan selisih pertambahan $26,875 \%$ yang bermakna media pop up book efektif difungsikan sebagai media pembelajaran untuk siswa.

Penelitian serupa juga dilakukan oleh Muhammad Amin yang berjudul Pengembangan Media Pop-Up Book Huruf Hijaiyah dalam Upaya Meningkatkan Motivasi Baca Santri Iqro'Jilid 1 di TPQ Baiturrahmah Malang. Hasil penelitian menunjukkan bahwa hasil validasi ahli media sebesar 96,25\%. Hasil pengesahan ahli materi diperoleh hasil persentase sebesar 93,75\%. Dan hasil angket tanggapan audien diperoleh persentase sebesar 93,00\%. Dapat ditarik simpulan bahwa bahan ajar pop-up dikelompokkan valid dan memadai dimanfaatkan untuk pembelajaran.

Uji coba ini dilakukan terhadap pelajar kelas V SDN Tegal Besar 1 dengan jumlah 27 siswa. Tiap-tiap siswa memiliki keunikan yang berlainan. Dengan perangkat pembelajaran pop up yang dikembangkan, guru mendapat peluang mengoptimalkan kegunaan sarana pembelajaran, sehingga pembelajaran yang terselenggara berjalan maksimal.

\section{METODE}

Metode yang diimplementasikan dalam penelitian ini adalah metode pengembangan dengan model pengembangan Dick \& Carey, terdiri dari sepuluh langkah yaitu, analisis kebutuhan dan tujuan, analisis pembelajaran, analisis pembelajar dan konteks, memformulasikan tujuan performansi, mengembangkan instrumen, mengembangkan taktik pembelajaran, mengembangkan dan menenentukan subjek pembelajaran, mengonsep dan mengadakan penilaian formatif, melakukan perbaikan, dan evaluasi sumatif. Tahap analisis kebutuhan dan tujuan merupakan tindakan mengidentifikasi kebenaran yang ada di lapangan melalui wawancara tak berpola dan pengamatan. Tahap analisis pembelajaran dilakukan untuk memadukankan data terkait keperluan belajar siswa. Tahap analisis pembelajar dan konteks merupakan analisis perilaku dan keunikan siswa dalam kelas. Tahap memformulasikan tujuan performansi yakni tahap pengolahanan standar kompetensi, kemudian pengembangan media pop-up disesuaikan dengan standar kompetensi yang ada. Tahap mengembangkan instrumen merupakan fase dimana instrumen pengukuran kualitas produk dikembangkan sesuai dengan tujuan operasional yang hendak di raih. Tahap mengembangkan siasat pembelajaran merupakan tahap menyusun RPP yang berfungsi untuk membantu siswa mencapai tujuan pembelajaran. Tahap mengembangkan dan menetapkan bahan pembelajaran merupakan tahap merancang media atau pra-produksi. Tahap membuat produk dan melaksanakan evaluasi formatif tahap produksi dan tahap validasi oleh para ahli. Tahap 
revisi merupakan tahap perbaikan sesuai dengan masukan para ahli. Tahap evaluasi sumatif merupakan tahap penentuan tingkat efektivitas produk.

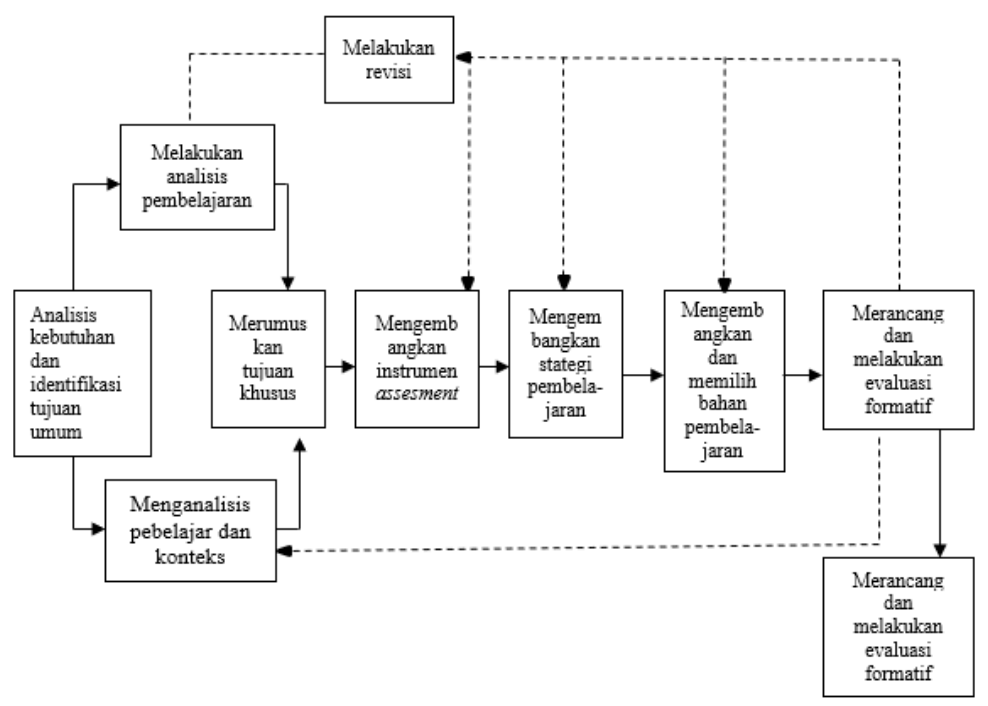

Gambar 1. Model Penelitian dan Pengembangan Dick \& Carey (Sumber: Setyosari, 2013: 230-235)

Subjek atas pengkajian ini yaitu anak kelas V SDN Tegal Besar 1 Jember yang berjumlah 27 orang. Pengumpulan data dalam penelitian ini dilakukan melalui observasi, wawancara dan angket. Observasi bertujuan untuk mengamati siswa saat berada dalam kelas. Wawancara dilakukan demi mendapati karakteristik siswa dan media yang dipakai saat proses belajar. Angket bertujuan untuk menilai kelayakan media pop-up yang dikembangkan. Pre-test dan post-test bertujuan untuk menguji efektivitas media pop-up yang dikembangkan. Analisis data yang digunakan analisis kualitatif dan kuantitatif. Data kualitatif didapatkan dari hasil observasi dan wawancara yang berupa paragraf deskriptif. Sedangkan data kuantatif didapatkan dari hasil penilaian oleh para ahli. Data hasil belajar siswa didapatkan dari nilai pre-test dan post-test untuk melihat keefektifan media buku pop-up.

Pengembang menggunakan aspek ukur sebagai berikut,efisiensi fungsi media buku pop-up, kejelasan buku pop-up, desain media, kesesuaian media pop-up dengan kurikulum, keefektifan penggunaan media pop-up book, sistematis penyajian materi pada media pop-up book, serta kemenarikan dan kejelasan media pop-up book.

\section{HASIL}

Media pop-up book yang dikembangkan berukuran A3. Pop-up book ini terdiri dari bagian awal yang berisi identifikasi produk, petunjuk penggunaan, dan kata pengantar. Bagian isi yang berupa materi daur air, materi peristiwa alam dan kuis. Serta bagian penutup yang berisi biografi pengembang.

Sebelum produk diimplementasikan, media pop-up book dinilai tingkat kelayakan/kevalidannya oleh para ahli. Kriteria tingkat kelayakan yang digunakan adalah tingkat kelayakan menurut Arikunto.

\begin{tabular}{cccc}
\hline Kategori & Prosentase & Kualifikasi & Ekuivalen \\
\hline A & $80 \%-100 \%$ & Valid & Layak \\
B & $60 \%-79 \%$ & Cukup Valid & Cukup Layak \\
C & $40 \%-59 \%$ & Kurang Valid & Kurang Layak \\
D & $0 \%-39 \%$ & Tidak Valid & Tidak Layak
\end{tabular}

Tabel 1. Kriteria Tingkat Kelayakan (Arikunto:2010)

Tingkat kevalidan dari hasil penilaian ahli media sebesar 96,59\%, dari hasil penilaian ahli materi sebesar 97,36\%. Penilain tersebut menujukkan bahwa pop-up book yang dikembangkan layak dan dapat dimanfaatkan dalam proses menimba ilmu. Untuk melihat tingkat keefektifan media pop-up book, peneliti memberikan tes yang dilaksanakan sebelum dan selepas penggunaan media untuk melihat perbedaan hasil menggali ilmu siswa. 


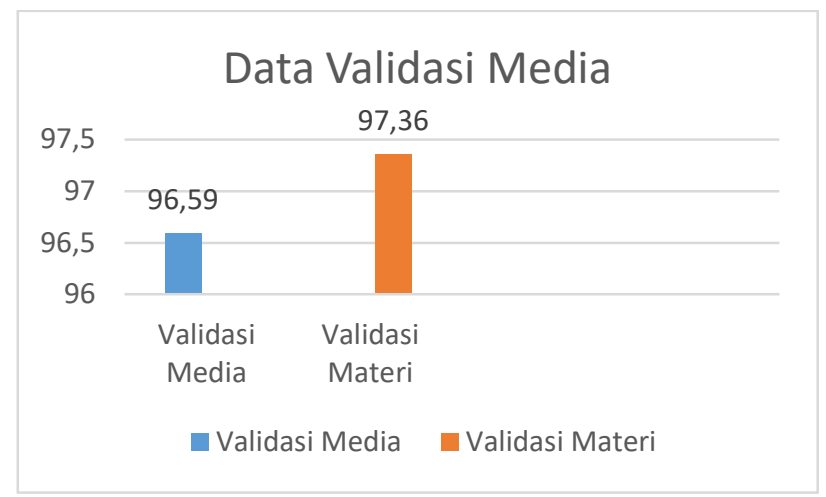

Gambar 2. Hasil validasi media

Melalui hasil implementasi, diperoleh pertambahan nilai ketika menggunakan media modul dan setelah menggunakan media pop-up. Pada saat pre-test beberapa siswa mendapatkan nilai yang rendah. Sebaliknya pada saat post-test nilai sebagian besar siswa meningkat dan mampu melebihi KKM. Dapat dirumuskan bahwa siswa terkesan belajar menggenakan buku pop-up tinimbang menggunakan buku teks belaka.

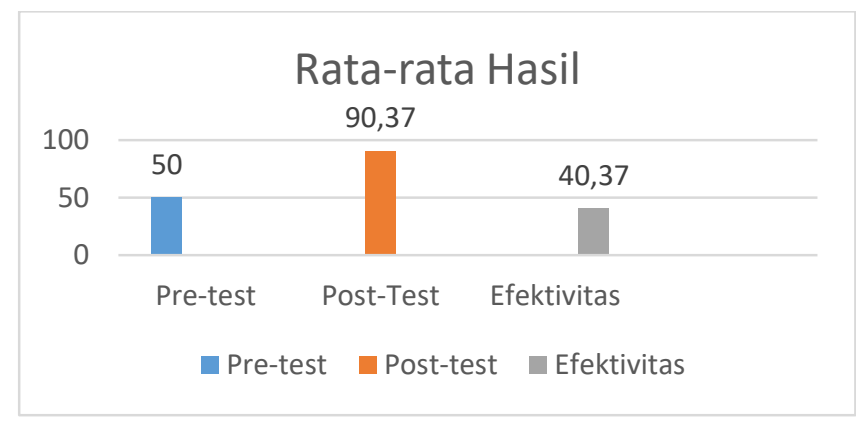

Gambar 3. Hasil implementasi media

\section{PEMBAHASAN}

Pop up book ialah sebuah kartu atau buku yang ketika dibuka bisa menyajikan konstruksi 3 dimensi atau timbul. Pop-Up Book ini disusun seinovatif mungkin sehingga mampu menambah ketertarikan belajar siswa yang akan berdampak pada hasil belajar siswa salah satunya dalam mata pelajaran Ilmu Pengetahuan Alam (Masturah:2018). Pop up book merupakan buku yang menampilkan halamanhalaman dimana terdapat lipatan gambar yang dipotong dan dibentuk berbagai lapisan hingga dapat terlihat 3 dimensi atau dapat pula digerakkan sehingga tidak membuat pembaca jenuh. (Sholikhah:2017). Pola gambar pada pop up book diatur sesuai dengan kebutuhan siswa.

Pengembangan media pop-up book serasi dengan paham AECT 2008. AECT 2008 mengungkapkan bahwa "teknologi pendidikan merupakan kajian dan etika praktik tentang memfasilitasi belajar dan memajukan kemampuan dengan menciptakan, memanfaatkan, dan mengatur proses serta sumber teknologi yang tepat". Sesuai dengan definisi tersebut maka sebagai teknolog pembelajaran dituntut untuk dapat menciptakan dan memfasilitasi pembelajaran salah satunya melalui media pembelajaran dimana dalam prosesnya mencakup kelima kawasan teknologi pendidikan tersebut secara terstruktur. (Widia Kusuma:2018)

Data mengenai tingkat kelayakan media pop up book diperoleh dari hasil validasi ahli media dan ahli materi. Hasil pengukuran oleh ahli media sebesar 96,59\%, dan dari hasil pertimbangan ahli materi sebesar $97,36 \%$. Ini menyatakan bahwa media pop up book yang dikembangkan termasuk kategori valid dan layak digunakan dalam proses pembelajaran..menurut arikunto (2010) media pembelajaran dikatakan valid apabila berkedudukan pada bentang persentase $76 \%-100 \%$. 
Media pop up book memiliki komponen yang mengandung unsur 3 dimensi, dimana ilustrasi bisa mencuat atau bergerak ketika halaman dibentang sehingga memberikan efek visual yang memukau (Dzuanda, 2011: 11). Hal ini akan mendukung meningkatkan respon belajar siswa yang positif. Terbukti dari hasil uji coba yang telah dilakukan pada 27 siswa didapati hasil sebesar 98,14\%. Menurut parameter keefektifan media, pop up di golongkan dalam kategori efektif.

Menurut Van Diyk (Ni'mah, 2014: 22) menyebutkan beberapa kelebihan dari media pop up book yaitu untuk menjelaskan materi yang memuat gambar secara kompleks, pop up book bisa digerakkan sebagai strategi untuk pembelajaran yang ampuh dan menghasilkan pembelajaran yang lebih mudah diingat, ilustrasi visual dalam pop up book dapat digunakan untuk memperjelas materi, pop up book memberikan pengalaman anyar bagi siswa, memikat ketertarikan siswa dan membuat pembelajaran menjadi seperti permainan yang memberikan kesempatan siswa untuk berpartisipasi didalamnya. Dimana kelebihan tersebut terbukti dari hasil uji coba yang telah dilakukan oleh pengembang. Pada saat pengembang melakukan uji coba media pop up book siswa terlihat lebih perhatian dan aktif terhadap materi yang disampaikan. Pernyataan tersebut juga disampaikan oleh guru mata pelajaran, menurutnya dengan media pop up book membantu menumbuhkan minat belajar siswa untuk belajar.

Idealnya, proses pembelajaran di sekolah dasar memberikan kesempatan bagi siswa untuk berperan aktif dalam proses pembelajaran melalui kegiatan belajar nyata yang dapat menambah rasa ingin tahu siswa. Sikap siswa dalam proses pembelajaran IPA dapat dikembangkan melalui diskusi, percobaan, simulasi, atau kegiatan di lapangan (Susanto, 2013: 169). Pelajaran IPA yang menarik bukan hanya pengetahuan tentang fakta, konsep, dan teori, tapi pembelajaran yang bermakna sehingga dapat merangsang rasa ingin tahu siswa tentang pembelajaran (Permana:2018).

Pada saat uji coba media dilakukan pengembang mendapatkan keterangan dari guru bahwa sikap siswa saat mengikuti pembelajaran dianggap berbeda antara pembelajaran konvensional yang dilakukan sebelumnya dengan pembelajaran menggunakan media. Guru menuturkan pada pembelajaran konvensional siswa terlihat lebih pasif dan kurang perhatian atau terkesan sibuk sendiri. Sementara pada pembelajaran yang disertai dengan media pop up book siswa lebih terlihat aktif dan perhatian, terkesan tenang antusias mengikuti pembelajaran yang dilaksanakan. Dengan demikian pengembang telah melihat perbedaan respon siswa antara sebelum dan sesudah penggunaan media pop up book.

Pembelajaran yang hanya menggunakan modul terkesan kurang menarik perhatian siswa. Hal tersebut selaras dengan hasil penelitian yang dilakukan oleh Sari (2017) yang menjelaskan bahwa siswa belum sepenuhnya menunjukkan motivasi belajar mandiri dengan membaca buku cetak. Hal ini terjadi karena modul yang digunakan oleh guru terkesan padat akan bacaan, gambar yang disajikan juga kurang mewakili isi dari materi. Dimana dengan kondisi yang demikian jelas kurang menarik siswa untuk belajar dan membaca, mengingat siswa pada jenjang Sekolah Dasar lebih tertarik dengan konten pembelajaran yang lebih berwarna dan unik.

Minat merupakan rasa suka dan rasa tertarik pada suatu hal dan aktivitas tertentu, tanpa ada yang menyuruh (Djaali, 2008:121). Teori ini selaras dengan hasil uji coba yang pengembang lakukan yaitu siswa terlihat lebih tertarik ditunjukkan dengan banyaknya pertanyaan dan antusias yang diberikan oleh siswa pada saat pembelajaran berlangsung. Menurut guru, media pop up book dapat membantu siswa dalam memahami materi, sehingga kemungkinan juga terdapat peningkatan hasil belajar. Pernyataan tersebut didukung dengan hasil dari pre-test dan post yang dikerjakan siswa.

Media pembelajaran pop up book sangat cocok untuk menciptakan suasana belajar yang bervariasi. Dengan adanya variasi dalam pembelajaran yang dilaksanakan dapat meningkatkan hasil belajar (Setyawan : 2013). Guru diharapkan mampu mengembangkan kemampuan penggunaan pop up book untuk mendukung terciptanya pembelajaran yang berkualitas. Sebab hal tersebut dapat mendukung tercapainya tujuan pembelajaran yang telah dirumuskan sebelumnya.

\section{SIMPULAN}

Penelitian pengembangan ini menghasilkan media pop-up yang sahih dan layak digunakan serta efektif membantu selama proses pembelajaran. Tingkat kevalidan pop-up book berdasarkan 
penghitungan ahli media sebesar 96,59, bedasarkan penilaian ahli materi sebesar 97,36\%. Situasi tersebut membuktikan bahwa pop-up book yang dikembangkan valid dan layak digunakan.

Efektivitas pop-up book dilihat dari hasil sebelum adanya media dan hasil sesudah pemakaian media. Bersumber pada hasil tersebut terdapat pertambahan nilai. Sebelum menggunakan pop-up book kebanyakan para siswa mendapat nilai dibawah KKM, sedangkan setelah menggunakan media pop-up book nilai siswa meningkat sehingga siswa mampu melampaui KKM. Hasil tersebut menunjukkan bahwa mayoritas siswa tertarik belajar mengenakan pop-up book daripada menggunakan buku teks saja.

\section{DAFTAR RUJUKAN}

Arikunto, S. (2010). Prosedur Penelitian Suatu Pendekatan Praktik. 2010. Jakarta: PT. Rineka Cipta.

Dewanti, H., Toenlioe, A. J., \& Soepriyanto, Y. (2019). Pengembangan Media Pop-Up Book Untuk Pembelajaran Lingkungan Tempat Tinggalku Kelas Iv Sdn 1 Pakunden Kabupaten Ponorogo. Jurnal Kajian Teknologi Pendidikan, 1(3), 221-228. http://journal2.um.ac.id/index.php/jktp/article/view/4551/3408

Djaali, H. (2008). Psikologi pendidikan. Jakarta: Bumi Aksara.

Dzuanda, B. (2009). Perancangan Buku Cerita Anak Pop-Up Tokoh-Tokoh Wayang Berseri, Seri "Gatotkaca". Skripsi). Institut Teknologi Sepuluh November, Surabaya.

Fatchul Mubarok F, M. (2014). Penerapan Media Dalam Bentuk Pop Up Book Pada Pembelajaran Unsur-Unsur Rupa Untuk Siswa Kelas 2 Sdnu Kanjeng Sepuh Sidayu Gresik. Jurnal Seni Rupa, 2(2). Retriefed From https://jurnalmahasiswa.unesa.ac.id/index.php/va/article/view/9888/9682

Masturah, E. D., Mahadewi, L. P. P., Simamora, A. H., \& SE, M. (2018). Pengembangan Media Pembelajaran Pop-Up Book Pada Mata Pelajaran Ipa Kelas Iii Sekolah Dasar. Jurnal EDUTECH Undiksha, 9(2). Retriefed From https://ejournal.undiksha.ac.id/index.php/JEU/article/view/14728

Mustofa, R., \& Syafi'ah, R. (2018). Pengembangan Media Pembelajaran Pop Up Book Materi Pokok Kenampakan Permukaan Bumi pada Mata Pelajaran IPA Kelas III SDN 1 Banaran Kecamatan Kauman Kabupaten Tulungagung. ELSE (Elementary School Education Journal): Jurnal Pendidikan dan Pembelajaran Sekolah Dasar, 2(2). Retriefed From http://journal.umsurabaya.ac.id/index.php/pgsd/article/view/1723

Ni'mah, Na'ilatun. (2014). Efektifitas Penggunaan Media Pop-Up dalam Pengajaran Keterampilan Berbicara Bahasa Perancis Siswa Kelas IX SMA Negeri 1 Mertoyudan Magelang. Skripsi. FBS-UNY

Permana, E. P., \& Sari, Y. E. P. (2018). Development of Pop Up Book Media Material Distinguishing Characteristics of Healthy and Unfit Environments Class III Students Elementary School. International Journal of Elementary Education, 2(1). Retriefed From https://ejournal.undiksha.ac.id/index.php/IJEE/article/view/13127

Sari, S. A. (2017). The Development of Pop-up Book on the Role of Buffer in the Living Body. European Journal of Social Science Education and Research, 4(4), 213-221. Retriefed From http://journals.euser.org/index.php/ejser/article/view/2430

Setyawan, D., \& Usada \& Mahfud, H. (2014). Penerapan Media Pop-Up Book untuk Meningkatkan Keterampilan Berbicara. Jurnal Didaktika Dwija Indria, 2(11), 1-5. Retriefed From https://jurnal.fkip.uns.ac.id/index.php/pgsdsolo/article/view/3986

Setyosari, P. (2013). Metode Penelitian Pendidikan dan Pengembangan. Jakarta:Kencana Prenadamedia Group.

Sholikhah, A. (2017). Pengembangan Media Pop-Up Book untuk Meningkatkan Kemampuan Menulis Kreatif pada Mata Pelajaran Bahasa Indonesia Materi Menulis karangan Kelas V SDN Rowoharjo Tahun Ajaran 2016/2017. Jurnal Simki Pedagogia, 1(08). Retriefed From http://simki.unpkediri.ac.id/mahasiswa/file artikel/2017/5ee12721ce5cc0d9ddc2f1e33ed818c3.pdf

Siregar, A., \& Rahmah, E. (2016). Model pop up book keluarga untuk mempercepat kemampuan membaca anak kelas rendah sekolah dasar. Ilmu Informasi Perpustakaan dan Kearsipan, 5(1), 10-21. Retriefed From http://ejournal.unp.ac.id/index.php/iipk/article/view/6288/4894

Widia Kusuma, R. A. N. I. (2017). Pengembangan Media Mobile Learning Berbasis Android Pada Pelajaran IPA Materi Pemuaian Untuk Siswa Kelas VII Di SMPN 1 Gondang Tulungagung. Jurnal Mahasiswa Teknologi Pendidikan, 9(1). Retriefed From https:/jurnalmahasiswa.unesa.ac.id/index.php/jmtp/article/view/22082 